\title{
Evaluation of Cytotoxicity and Antifertility Effect of Artemisia kopetdaghensis
}

\author{
Davood Oliaee, ${ }^{1}$ Mohammad Taher Boroushaki, ${ }^{2,3}$ Naiime Oliaee, ${ }^{2}$ and Ahmad Ghorbani ${ }^{2}$ \\ ${ }^{1}$ Student Research Committee, Mashhad University of Medical Sciences, Mashhad 913750345, Iran \\ ${ }^{2}$ Pharmacological Research Center of Medicinal Plants, School of Medicine, Mashhad University of Medical Sciences, \\ Mashhad 9177948564, Iran \\ ${ }^{3}$ Department of Pharmacology, School of Medicine, Mashhad University of Medical Sciences, Mashhad 9177948564, Iran
}

Correspondence should be addressed to Ahmad Ghorbani; ghorbania@mums.ac.ir

Received 14 December 2013; Accepted 4 February 2014; Published 10 March 2014

Academic Editor: Berend Olivier

Copyright (C) 2014 Davood Oliaee et al. This is an open access article distributed under the Creative Commons Attribution License, which permits unrestricted use, distribution, and reproduction in any medium, provided the original work is properly cited.

To date, there is no report on safety of Artemisia Kopetdaghensis. This study aimed to determine the possible undesirable effects of $A$. Kopetdaghensis on reproduction of female rats. The pregnant rats were treated (i.p.) with vehicle or $200 \mathrm{and} 400 \mathrm{mg} / \mathrm{kg}$ of $A$. Kopetdaghensis hydroalcoholic extract from the 2nd to 8th day of pregnancy. Then, number and weight of neonates, duration of pregnancy, and percent of dead fetuses were determined. Also, cytotoxicity of this plant was tested using fibroblast (L929) and ovary (Cho) cell lines. The A. Kopetdaghensis had no significant effect on duration of pregnancy, average number of neonates, and weight of neonates. However, administration of 200 and $400 \mathrm{mg} / \mathrm{kg}$ of the extract led to 30 and $44 \%$ abortion in animals, respectively. The extract at concentrations $\geq 200 \mu \mathrm{g} / \mathrm{mL}$ significantly $(P<0.001)$ inhibited the proliferation of L929 fibroblast cells. Regarding the Cho cells, the extract induced toxicity only at concentration of $800 \mu \mathrm{g} / \mathrm{mL}(P<0.01)$. Our results showed that continuous consumption of $A$. Kopetdaghensis in pregnancy may increase the risk of abortion and also may have toxic effect on some cells.

\section{Introduction}

Today, medicinal plants are widely used around the world as an alternative to pharmaceutical drugs. Although herbal products are considered to have fewer adverse effects compared with synthetic drugs, they are not completely free from side effects or toxicity [1]. Adverse effects of medicinal plants may result from contamination of herbs with toxic metals, adulteration with active synthetic compounds, improperly prepared herbal products, misidentification of herbal ingredients, and inherent toxicity of certain herbs [2]. Therefore, the potential side effects of any medicinal plant need to be determined before its clinical applications. Special care should be taken when a herbal product is used by pregnant women, children, and geriatrics. Unfortunately, unlike those synthetic drugs not recommended for use in pregnancy because of known unwanted effects, there are insufficient data about undesirable maternal and perinatal consequences of use of herbal agents.
Artemisia kopetdaghensis, aromatic shrubs belonging to the Asteraceae family, is traditionally used in Iran for its anti-inflammatory, antimicrobial, antifungal, and sedative activities [3, 4]. However, to date, there is no report on safety or toxicity of this plant. Only Ebrahimi and coworkers reported that methanolic extract and essential oil of $A$. kopetdaghensis exhibited tumor growth induction at some concentrations and cytotoxicity at other concentrations [5]. The aim of the present study was to determine the possible undesirable effects of $A$. kopetdaghensis on reproduction of female rats. Also, the possible cytotoxicity of this plant was assessed using fibroblast and ovary cells in vitro.

\section{Materials and Methods}

2.1. Chemicals and Reagents. High glucose Dulbecco's Modified Eagles Medium (DMEM) and fetal bovine serum were purchased from Gibco. Penicillin, streptomycin, and 
TABLE 1: Effect of Artemisia kopetdaghensis on reproduction of female rats. The pregnant rats were treated (i.p.) with vehicle or A. kopetdaghensis hydroalcoholic extract from the 2th to 8 th day of pregnancy. Values are mean \pm SEM $(n=8-10)$.

\begin{tabular}{lccc}
\hline Animal groups & Duration of pregnancy (day) & Abortion (\%) & Percent of dead fetuses (\%) \\
\hline Control & $22 \pm 0.3$ & 0 & 6 \\
A. kopetdaghensis $(200 \mathrm{mg} / \mathrm{kg})$ & $23 \pm 0.3$ & 30 & 7 \\
A. kopetdaghensis $(400 \mathrm{mg} / \mathrm{kg})$ & $22 \pm 0.4$ & 44 & 0 \\
\hline
\end{tabular}

3-(4,5-Dimethyl-2-thiazolyl)-2,5-Diphenyl-2H-tetrazolium bromide (MTT) were obtained from Sigma. Dimethyl sulfoxide (DMSO) was purchased from Fluka. Tween 80 was purchased from Merck.

2.2. Preparation of Plant Extract. The fresh A. kopetdaghensis was collected from Gonabad (Eastern area of Iran) and identified by the herbarium of Ferdowsi University of Mashhad, Iran (voucher specimen number: 35205). The aerial parts of plant were cleaned and grounded to fine powder with a blender. Then, macerated extract was prepared as described previously [6,7], briefly by suspension of $200 \mathrm{~g}$ of the powder in $500 \mathrm{~mL}$ of $50 \%$ ethanol and incubation for $72 \mathrm{~h}$ at $37^{\circ} \mathrm{C}$. The hydroalcoholic extract was then dried on a water bath and the yield dissolved in distilled water containing 1\% Tween 80 .

2.3. Animals. Male and female Wistar rats (200-250 g) and female mice (26-32 g) were obtained from Laboratory Animals Research Center, Mashhad University of Medical Sciences (Iran) and housed in a room with controlled lighting $(12 \mathrm{~h}$ dark, $12 \mathrm{~h}$ light $)$ and temperature $\left(22 \pm 2^{\circ} \mathrm{C}\right)$. The animals were given standard pellets diet and water ad libitum. All animal procedures were in accordance with ethical guidelines approved by the Animal Care Use Committee of Shiraz University of Medical Sciences (Iran).

2.4. Evaluation of A. kopetdaghensis Effect on Reproduction. Prior to the mating, the female rats were isolated for 30 days to rule out preexisting pregnancy. Then, they were caged overnight with a male rat of proven fertility in the ratio of $1: 1$. Rats exhibiting vaginal plug on the following morning were separated, and that day was considered as the first day of pregnancy. The pregnant rats were randomized into three groups: (1) control group receiving $1 \%$ Tween 80 as vehicle $(n=8),(2)$ experimental rats treated with $200 \mathrm{mg} / \mathrm{kg}$ of $A$. kopetdaghensis extract $(n=10)$, and (3) experimental rats receiving $400 \mathrm{mg} / \mathrm{kg}$ of the plant extract $(n=9)$. The extract was injected intraperitoneally from the 2 nd to the 8 th day of pregnancy (early period of organogenesis). The animals were kept individually in cages until parturition. Then, number and weight of neonates, duration of pregnancy, and percent of dead fetuses were determined.

2.5. Acute Toxicity Determination. Acute toxicity of $A$. kopetdaghensis extract was evaluated by the method of Akhila et al. [8], as described in our previously published work [9]. Five groups of two mice received vehicle (1\% Tween 80 ) or $400,800,1600$, and $3200 \mathrm{mg} / \mathrm{kg}$ of the plant extract intraperitoneally. The treated animals were monitored for
$24 \mathrm{~h}$ and also one week for mortality. The lowest dose which led to death of animals and the highest dose which did not kill any mice were recorded.

2.6. Cytotoxicity Assessment. The L929 (mouse fibroblast) and Cho (Chinese hamster ovary) cells were seeded in 96well plates and cultured for $24 \mathrm{~h}$ in DMEM supplemented with $10 \%$ FBS, penicillin (100 units $/ \mathrm{mL}$ ), and streptomycin $(100 \mu \mathrm{g} / \mathrm{mL})$ at $37^{\circ} \mathrm{C}$ and $5 \% \mathrm{CO}_{2}$. Then, the medium was changed to fresh one containing vehicle (1\% DMSO) or $50-$ $800 \mu \mathrm{g} / \mathrm{mL}$ of $A$. kopetdaghensis extract. The cells were further incubated for $24 \mathrm{~h}$ at $37^{\circ} \mathrm{C}$ and $5 \% \mathrm{CO}_{2}$. At the end of the treatment, the cell proliferation was measured using MTT assay as previously described [10-12]. The assay was carried out using 2 culture plates, 4 wells for each concentration $(n=$ 8).

2.7. Statistical Analysis. The values were compared using the one-way analysis of variance (ANOVA) followed by Tukey's post hoc test for multiple comparisons. The $P$ values less than 0.05 were considered to be statistically significant. All results are presented as mean \pm SEM.

\section{Results}

3.1. Effect of A. kopetdaghensis on Reproduction. As shown in Table 1, the A. kopetdaghensis extract at concentrations of 200 and $400 \mathrm{mg} / \mathrm{kg}$ had no significant effect on duration of pregnancy. However, administration of 200 and $400 \mathrm{mg} / \mathrm{kg}$ of the extract led to 30 and $44 \%$ abortion in animals, respectively. The percent of dead neonates was $6 \%$ in control group and $7 \%$ and $0 \%$ in experimental groups treated with 200 and $400 \mathrm{mg} / \mathrm{kg}$, respectively. The average number of the neonates in the animals receiving vehicle during pregnancy was $8.13 \pm 1.5$ (Figure 1(a)). None of the A. kopetdaghensis doses could cause a significant change in the neonate number. Likewise, the extract had virtually no significant effect on weight of neonates (Figure 1(b)).

3.2. Acute Toxicity of A. kopetdaghensis. Different groups of mice $(n=2)$ were treated with 400, 800, 1600, and $3200 \mathrm{mg} / \mathrm{kg}$ of $A$. kopetdaghensis hydroalcoholic extract. After $24 \mathrm{~h}$, it was found that 1600 and $3200 \mathrm{mg} / \mathrm{kg}$ are the highest dose which did not kill any mice and the lowest dose which led to death of both mice, respectively. The treated animals were further monitored until one week and no mortality or any sign of toxicity was observed at doses $\leq 1600 \mathrm{mg} / \mathrm{kg}$. 


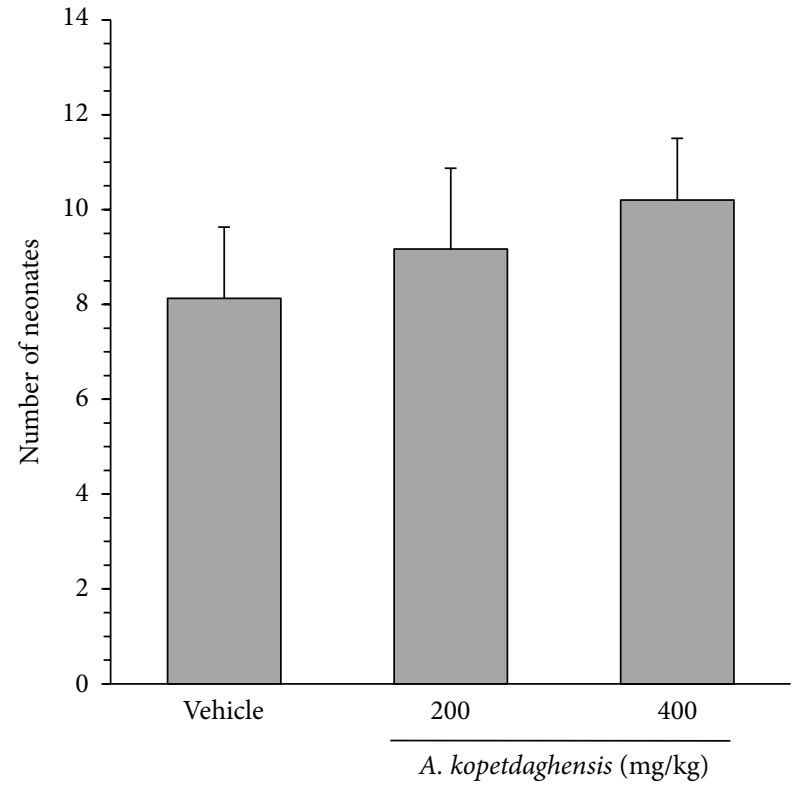

(a)

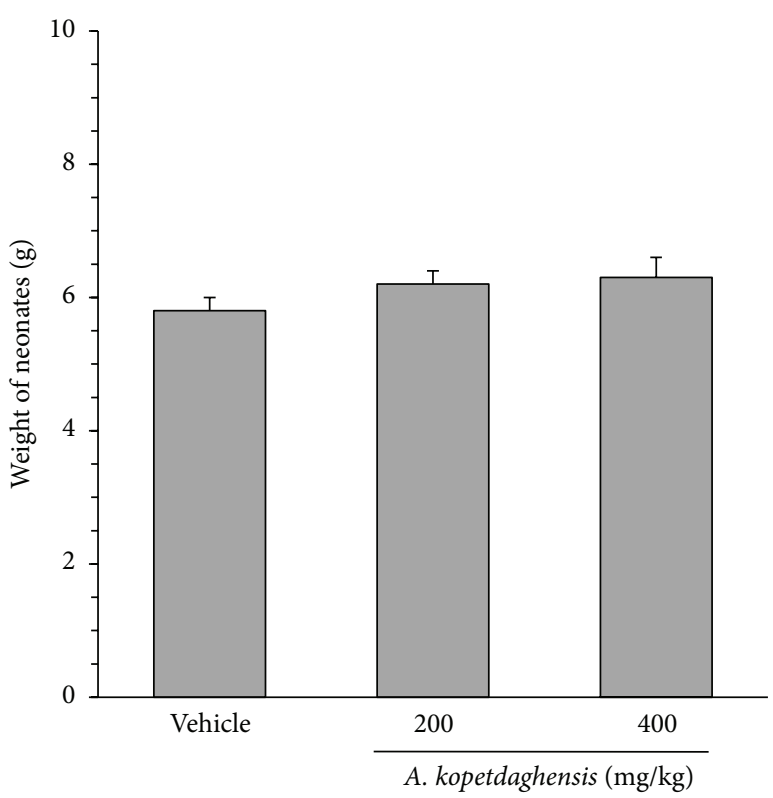

(b)

Figure 1: Effect of Artemisia kopetdaghensis hydroalcoholic extract on number (a) and weight (b) of neonates. The pregnant rats were treated (i.p.) with vehicle or 200 and $400 \mathrm{mg} / \mathrm{kg}$ of $A$. kopetdaghensis hydroalcoholic extract from the 2 th to 8 th day of pregnancy. Values are mean \pm $\operatorname{SEM}(n=8-10)$.

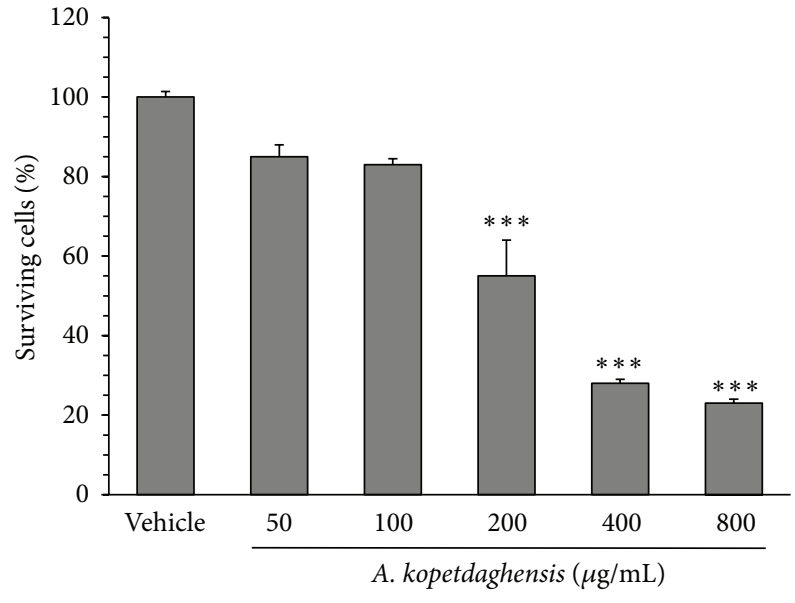

(a)

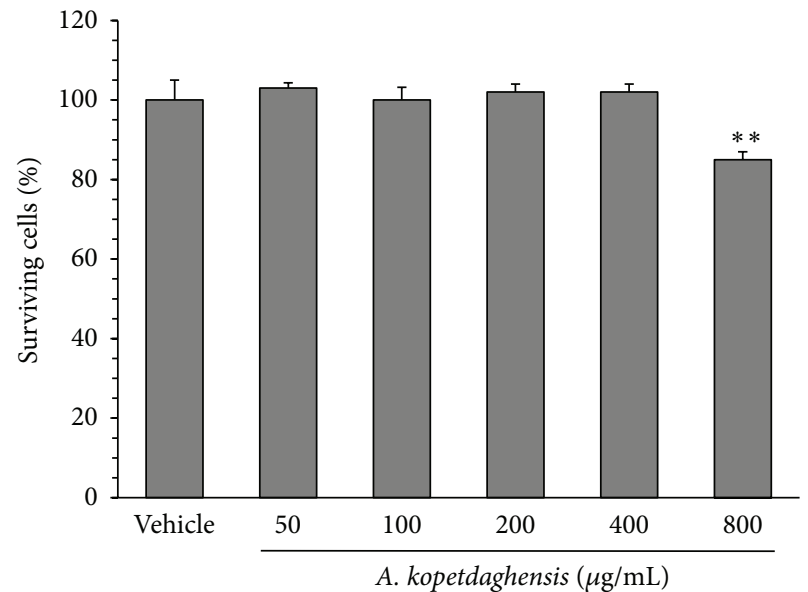

(b)

FIGURE 2: Effect of Artemisia kopetdaghensis hydroalcoholic extract on proliferation of fibroblast L929 (a) and Cho (b) cell lines. The cells were cultured for $24 \mathrm{~h}$ in the medium containing vehicle (1\% DMSO) or $50-800 \mu \mathrm{g} / \mathrm{mL}$ of $A$. kopetdaghensis extract. Values are mean \pm SEM $(n=8)$.

3.3. Cytotoxicity of A. kopetdaghensis. Figure 2 shows the effect of $A$. kopetdaghensis hydroalcoholic extract on proliferation of L929 and Cho cells. Following incubation of L929 fibroblast cells with $50,100,200,400$, and $800 \mu \mathrm{g} / \mathrm{mL}$ of the extract, approximately $15,17,45,72$, and $77 \%$ inhibition in cell growth, was observed, respectively, as compared with untreated cells. The cytotoxic effect of $A$. kopetdaghensis was statistically significant at concentrations $\geq 200 \mu \mathrm{g} / \mathrm{mL}(P<$ $0.001)$. On the other hand, the extract induced toxicity on Cho cells only at concentration of $800 \mu \mathrm{g} / \mathrm{mL}(P<0.01)$.
In the presence of 50, 100, 200, 400 and $800 \mu \mathrm{g} / \mathrm{mL}$ of $A$. kopetdaghensis, surviving of Cho cells was $103 \pm 1.3,100 \pm 3.2$, $102 \pm 2,102 \pm 2$ and $85 \pm 2 \%$, respectively, as compared to untreated cells $(100 \pm 5)$.

\section{Discussion}

Many medicinal plants are used by pregnant women for their therapeutic effects. For example, it has been shown that 
about $36 \%$ of pregnant women in Norway use herbs [13]. However, these plants are consumed mostly based on personal experience or traditional knowledge and in most cases it is unclear how safe the use of them is during pregnancy. Previous studies highlighted that some of plants have different antifertility activities [14]. The present study was aimed to examine the possible toxic effects of $A$. kopetdaghensis on reproduction of female rats. Our data demonstrated that the plant extract has no effect on duration of pregnancy and number or weight of neonates. However, it can induce abortifacient effect when consumed at early period of pregnancy. This antifertility effect of $A$. kopetdaghensis has been also reported for some other plants of the Asteraceae family such as Achillea millefolium and Aspilia africana which showed antispermatogenic and antiovulatory activities, respectively $[15,16]$. On the other hand, we observed that administration of A. kopetdaghensis extract $(400 \mathrm{mg} / \mathrm{kg})$ did not lead to stillbirth. The exact cause of this discrepancy should be explored in the future experiments. However, it may be attributed to high rate of abortion in animals receiving high concentration of the extract.

According to the previously published work, camphene, camphor, davanone, eucalyptol, eugenol, and geranial are of major components of A. kopetdaghensis. Camphor accounted for about $1.5 \mathrm{~g} / 100 \mathrm{~g}$ of this plant [17]. Rabl and coworkers have reported that camphor crosses the placenta and may lead to abortion [18]. In another study, Linjawi reported that camphor induces significant structural changes on uterus of pregnant rats [19]. Therefore, it is rational to assume that camphor is involved in the abortifacient effect of $A$. kopetdaghensis.

Cytotoxicity evaluation of A. kopetdaghensis showed that its hydroalcoholic extract decreases proliferation of fibroblast cells. This finding may describe the camphor induced degeneration of luminal epithelium and decrease of endometrium thickness in uterus of pregnant animals [19].

In conclusion, our results showed that continuous consumption of $A$. kopetdaghensis in pregnancy may increase the risk of abortion and also may have toxic effect on some cells of body. Therefore, its continuous use is not recommended in pregnancy.

\section{Conflict of Interests}

The authors declare that there is no conflict of interests regarding the publication of this paper.

\section{Acknowledgment}

This work was supported by Vice Chancellor for Research, Mashhad University of Medical Sciences, Mashhad, Iran.

\section{References}

[1] P. A. G. M. De Smet, "Health risks of herbal remedies: an update," Clinical Pharmacology and Therapeutics, vol. 76, no. 1, pp. 1-17, 2004.

[2] S. A. Jordan, D. G. Cunningham, and R. J. Marles, "Assessment of herbal medicinal products: challenges, and opportunities to increase the knowledge base for safety assessment," Toxicology and Applied Pharmacology, vol. 243, no. 2, pp. 198-216, 2010.

[3] M. Ramezani, J. Behravan, and A. Yazdinezhad, "Composition and antimicrobial activity of the volatile oil of Artemisia kopetdaghensis Krasch., M.Pop. \& Linecz ex Poljak from Iran," Flavour and Fragrance Journal, vol. 21, no. 6, pp. 869-871, 2006.

[4] S. Z. Mirdeilami, H. Barani, M. Mazandarani, and G. A. Heshmati, "Ethnopharmacological survery of medicinal plants in Marraveh Tappeh region, north of Iran," Iranian Journal of Plant Physiology, vol. 2, pp. 327-380, 2011.

[5] M. Ebrahimi, M. Ramezani, S. O. Tehrani, O. M. Malekshah, and J. Behravan, "Cytotoxic effects of methanolic extract and essential oil of Artemisia Kopetdaghensis," Journal of Essential Oil-Bearing Plants, vol. 13, no. 6, pp. 732-737, 2010.

[6] A. Ghorbani, M. R. Hadjzadeh, Z. Rajaei, and S. B. Zendehbad, "Effects of fenugreek seeds on adipogenesis and lipolysis in normal and diabetic rat," Pakistan Journal of Biological Sciences, vol. 17, no. 4, pp. 523-528, 2014.

[7] R. Shafiee-Nick, A. Ghorbani, F. Vafaee, and H. Rakhshandeh, "Chronic administration of a combination of six herbs inhibits the progression of hyperglycemia and decreases serum lipids and aspartate amino transferase activity in diabetic rats," Advances in Pharmacological Sciences, vol. 2012, Article ID 789796, 6 pages, 2012.

[8] A. Ghorbani, H. Rakhshandeh, and H. R. Sadeghnia, "Potentiating effects of Lactuca sativa on pentobarbital-induced sleep," Iranian Journal of Pharmaceutical Research, vol. 12, pp. 401-406, 2013.

[9] J. S. Akhila, S. Shyamjith, D. Deepa, and M. C. Alwar, "Acute toxicity studies and determination of median lethal dose," Current Science, vol. 93, no. 7, pp. 917-920, 2007.

[10] F. Forouzanfar, A. A. Goli, E. Assadpour, A. Ghorbani, and H. R. Sadeghnia, "Protective effect of Punica granatum L. against serum/glucose deprivation-induced PC12 cells injury," Evidence-Based Complementary and Alternative Medicine, vol. 2013, Article ID 7167730, 9 pages, 2013.

[11] S. M. Mortazavian and A. Ghorbani, "Antiproliferative effect of viola tricolor on neuroblastoma cells in vitro," Australian Journal of Medical Herbalism, vol. 24, pp. 93-96, 2010.

[12] S. M. Mortazavian, A. Ghorbani, and T. G. Hesari, "Effect of hydro-alcoholic extract of Viola tricolor and its fractions on proliferation of uterine cervix carcinoma cells," The Iranian Journal of Obstetrics, Gynecology and Infertility, vol. 15, pp. 916, 2012.

[13] H. Nordeng and G. C. Havnen, "Use of herbal drugs in pregnancy: a survey among 400 Norwegian women," Pharmacoepidemiology and Drug Safety, vol. 13, no. 6, pp. 371-380, 2004.

[14] G. Priya, K. Saravanan, and C. Renuka, "Medicinal plants with potential antifertility activity-a review of sixteen years of herbal medicine research (1994-2010)," International Journal of PharmTech Research, vol. 4, pp. 481-494.

[15] T. Montanari, J. E. De Carvalho, and H. Dolder, "Antispermatogenic effect of Achillea millefolium L. in mice," Contraception, vol. 58, no. 5, pp. 309-313, 1998.

[16] T. O. Oyesola, O. A. Oyesola, and C. S. Okoye, "Effects of aqueous extract of Aspilia Africana on reproductive functions of female wistar rats," Pakistan Journal of Biological Sciences, vol. 13, no. 3, pp. 126-131, 2010.

[17] R. Costa, M. R. De Fina, M. R. Valentino et al., "An investigation on the volatile composition of some Artemisia species from Iran," Flavour and Fragrance Journal, vol. 24, no. 2, pp. 75-82, 2009. 
[18] W. Rabl, F. Katzgraber, and M. Steinlechner, "Camphor ingestion for abortion (case report)," Forensic Science International, vol. 89, no. 1-2, pp. 137-140, 1997.

[19] S. A. Linjawi, "Effect of camphor on uterus histology of pregnant rats," Journal of King Abdulaziz University, vol. 16, no. 2, pp. 7790, 2009. 

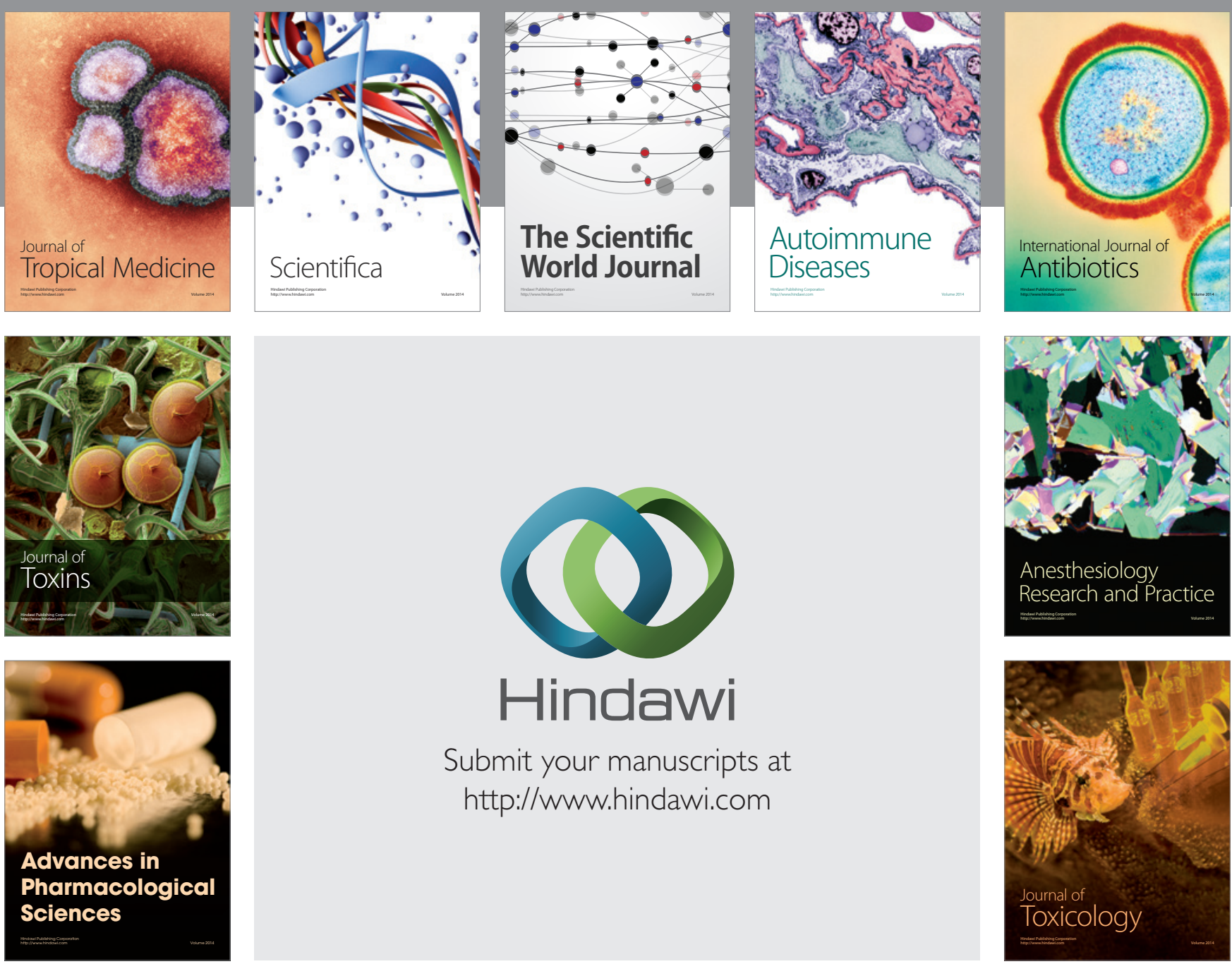

\section{Hindawi}

Submit your manuscripts at

http://www.hindawi.com
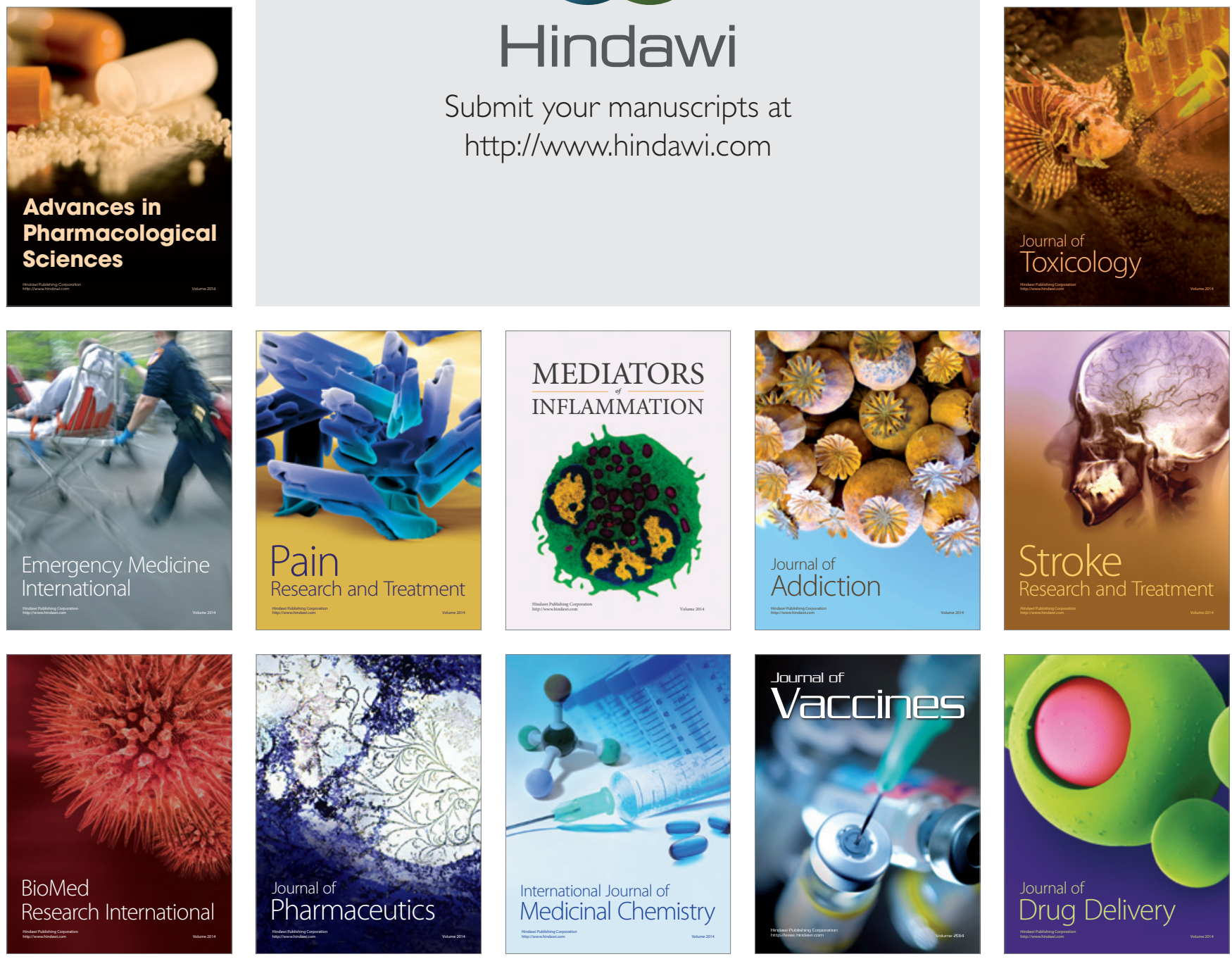